Original Research Article

\title{
Potential anti-seizure activity of atorvastatin in rat models of seizure
}

\author{
Ashwini P. Singh*, Radhika M. S.
}

Department of Pharmacology, SDM College of Medical Sciences and Hospital, Dharwad, Karnataka, India

Received: 21 November 2016 Accepted: 12 December 2016

*Correspondence to: Dr. Ashwini P. Singh, Email: roshnisingh891@gmail.com

Copyright: (C) the author(s), publisher and licensee Medip Academy. This is an openaccess article distributed under the terms of the Creative Commons Attribution NonCommercial License, which permits unrestricted noncommercial use, distribution, and reproduction in any medium, provided the original work is properly cited.

\begin{abstract}
Background: Atorvastatin belongs to the class of Hypolipidemic statins. Increasing evidence indicates that statins are neuroprotective in several conditions, including stroke, cerebral ischemia and traumatic brain injury. However, only scanty and controversial reports are available on anticonvulsant action of statins. The present study therefore aims at exploring the influence of atorvastatin on seizures as compared to standard anticonvulsants phenytoin and sodium valproate in Wistar rats.

Methods: Rats were divided into 8 groups $(n=6)$, each treated intraperitoneally (i.p) with atorvastatin, phenytoin or sodium valproate in their therapeutic equivalent doses. Their effects were evaluated on seizures induced by maximum electroshock seizure (MES) and pentylenetetrazole (PTZ). Hind limb extension (HLE) in MES model, number of seizures, duration of seizure, number of myoclonic jerks and time for onset as well as recovery from seizures in PTZ model were monitored. Statistical analysis was done using Kruskal-Wallis ANOVA and Mann-Whitney U test for significance.

Results: Atorvastatin failed to protect rats against HLE in MES seizure model. However, atorvastatin significantly prolonged seizure onset time $(p<0.0547)$, decreased seizure number $(p<0.0082)$, seizure duration $(p<0.0547)$ and recovery time $(\mathrm{p}<0.0040)$ in PTZ model indicating its potential antiepileptic activity in PTZ model.

Conclusions: Atorvastatin exhibited protection against seizures only in PTZ seizure model. Hence, it could possess anti absence seizure activity. This needs to be established with further systematic animal and clinical studies.
\end{abstract}

Keywords: Anticonvulsant, Atorvastatin, Maximal electroshock (MES), Pentylenetetrazole (PTZ), Phenytoin, Sodium valproate

\section{INTRODUCTION}

Epilepsy is chronic non-communicable disorder of brain that affects people of all ages and occurs in approximately $0.7 \%$ of the population at any one time in the life span. ${ }^{1}$ The currently available anticonvulsant drugs are neither effective prophylactically nor curatively, but are valuable only symptomatically. Consequently further studies in the quest to explore an ideal anticonvulsant agent having more specific, effective and safer pharmacological profile continues. Neuronal hyper-excitability and excessive production of free radicals have been implicated in the pathogenesis of a considerable range of neurological disorders; including epilepsy. $^{2}$

Atorvastatin is competitive inhibitor of HMG-CoA (3hydroxy-3-methylglutaryl-coenzyme A) reductase enzyme which catalyzes the rate limiting step in cholesterol biosynthesis, thus used in treatment of dyslipidaemia. In addition to reducing the serum cholesterol levels, statins have various pleiotropic effects such as increasing nitric oxide (NO), reducing oxidative stress, neuroinflammation, and neurotoxicity. ${ }^{3}$ Increasing evidence indicates that statins are neuroprotective in various conditions, including stroke, cerebral ischemia and traumatic brain injury. ${ }^{3}$ As statins possess antioxidant, neuroprotective effects, they may be expected to possess antiepileptic activity too. However, only scanty reports are available on anticonvulsant action of statins and in them some comprise controversial reports of atorvastatin on experimental seizure models. ${ }^{4,5}$ Studies performed by Jayaram R and Kumar S using atorvastatin in MES model exhibited no protection against HLE. ${ }^{6,7}$ Whereas in study performed by Nayak $\mathrm{V}$ atorvastatin did afford protection against HLE in MES model. ${ }^{8}$ A few authors have reported protection against PTZ induced seizures on acute administration of atorvastatin and a few others conclude its beneficial effects on chronic administration. 
Thus, due to the above mentioned discrepancy regarding anticonvulsant activity of atorvastatin the present study was attempted at exploring the possible anticonvulsant effect of atorvastatin in animal models of epilepsy.

\section{METHODS}

\section{Experimental animals}

Healthy adult male Wistar rats of average weight $150 \pm 30$ $\mathrm{g}$ (procured from central animal house of the institute), maintained on standard pellet feed obtained from Nutritive Life Sciences, Pune were used. They were acclimatized to departmental laboratory conditions for a week and a $12 \mathrm{~h}$ light and dark cycle was maintained. The animals were fasted overnight allowing access to water ad libitum prior to the day of experimentation. The study was approved by Institutional Animal Ethical Committee constituted as per CPCSEA guidelines.

\section{Drugs and chemicals}

Atorvastatin (Mankind Pharmaceutical Limited), Phenytoin (Mankind Pharmaceutical Limited) were given as generous gift samples, Sodium valproate (Rajesh Chemicals, Mumbai), PTZ (Sigma-Aldrich, Bengaluru) were purchased from respective companies.

\section{Experimental methods}

The test and standard drugs were dissolved in normal saline using magnetic stirrer to ensure a homogeneous solution for injection.

\section{Table 1: Test groups.}

\begin{tabular}{|lll|}
\hline Group (n=6) & MES Model & PTZ Model \\
\hline $\begin{array}{l}\text { Group 1 } \\
\text { (control) }\end{array}$ & Normal saline 1 & Normal saline 1 \\
$\mathrm{ml} / \mathrm{kg}$ & $\mathrm{ml} / \mathrm{kg}$ \\
\hline $\begin{array}{l}\text { Group 2 } \\
\text { (standard) }\end{array}$ & Phenytoin 36 & Sodium valproate \\
\hline Group 3 & Atorvastatin 3.6 & Atorvastatin 3.6 \\
(test A) & $\mathrm{mg} / \mathrm{kg}$ & $\mathrm{mg} / \mathrm{kg}$ \\
\hline Group 4 & Atorvastatin 7.5 & Atorvastatin 7.5 \\
(test B) & $\mathrm{mg} / \mathrm{kg}$ & $\mathrm{mg} / \mathrm{kg}$ \\
\hline
\end{tabular}

\section{Maximal electroshock (MES) model}

Adult male Wistar rats of an average weight between $150 \pm 30 \mathrm{~g}$ were subjected to electroshock of $150 \mathrm{~mA}$ for 0.2 seconds, through transauricular electrodes (covered in cotton wool and saline moistened). Only those rats which exhibited HLE during the screening procedure a day prior to MES studies were included in the study. The animal received atorvastatin/phenytoin/normal saline, i.p. 30 min before the application of electroshock. Absence of HLE was taken as an indication of protection against seizure and significant protection in treated group vs control group was analysed.

\section{PTZ induced seizure model}

Adult male Wistar rats of average weight $150 \pm 30 \mathrm{~g}$ in each group were pretreated with the test atorvastatin/sodium valproate/normal saline i.p. After 30 min PTZ was administered at a dose of $50 \mathrm{mg} / \mathrm{kg}$ i.p and observed for the convulsive behavior for 1 hour. The parameters noted were: seizure latency (time taken for onset of seizures), mean seizure number, mean seizure duration, number of myoclonic jerks and recovery time.

\section{Statistical analysis}

The data was represented as percentage protection in MES model and in the PTZ model data was analysed by Kruskal-Wallis ANOVA and Mann Whitney U test. p valve $<0.05$ was considered significant.

\section{RESULTS}

\section{MES model}

Atorvastatin in therapeutic equivalent doses of $3.6 \mathrm{mg} / \mathrm{kg}$ and $7.5 \mathrm{mg} / \mathrm{kg}$ did not offer protection against HLE in the MES seizure model. Whereas phenytoin in therapeutic equivalent dose of $36 \mathrm{mg} / \mathrm{kg}$ offered $100 \%$ protection against HLE in the MES seizure model (Table 2).

Table 2: Percentage protection against HLE induced by MES.

\begin{tabular}{|lllll|}
\hline \multirow{2}{*}{ Group (n=6) } & $\begin{array}{l}\text { Drug dose } \\
(\mathbf{m g} / \mathrm{kg})\end{array}$ & \multicolumn{2}{l|}{ HLE } & \% \\
\cline { 3 - 5 } & $\mathbf{( + )}$ & $\mathbf{( - )}$ & protection \\
\hline Normal saline & $1 \mathrm{ml} / \mathrm{kg}$ & 6 & 0 & 0 \\
\hline Phenytoin & 36 & 0 & 6 & $100^{*}$ \\
\hline Atorvastatin & 3.6 & 6 & 0 & 0 \\
\hline Atorvastatin & 7.5 & 5 & 1 & 16.6 \\
\hline $\begin{array}{l}\text { Atorvastatin } \\
\text { +Phenytoin }\end{array}$ & $7.5+13.5$ & 5 & 1 & 16.6 \\
\hline$*$ p $<0.05$ & & & & \\
\hline
\end{tabular}

\section{PTZ model}

Atorvastatin in the doses of $3.6 \mathrm{mg} / \mathrm{kg}$ and $7.5 \mathrm{mg} / \mathrm{kg}$ significantly prolonged seizure onset time $(\mathrm{p}<0.0547)$, decreased seizure number $(\mathrm{p}<0.0082)$, seizure duration $(\mathrm{p}<0.0547)$, and recovery time $(\mathrm{p}<0.0040)$ in the PTZ model (Table 3 ).

\section{DISCUSSION}

The present study was planned to investigate the influence of atorvastatin on different models of seizure in Wistar rats. The study aimed at assessing the antiepileptic activity of atorvastatin compared to standard antiepileptic drugs, phenytoin and sodium valproate in MES and PTZ models. 
Table 3: Effect of Atorvastatin and sodium valproate on various parameters in the PTZ model.

\begin{tabular}{|lllllllllll|}
\hline \multirow{2}{*}{ Groups } & $\begin{array}{l}\text { Seizure onset } \\
\text { time }\end{array}$ & $\begin{array}{l}\text { Seizure } \\
\text { number }\end{array}$ & \multicolumn{3}{l}{$\begin{array}{l}\text { Seizure } \\
\text { duration }\end{array}$} & \multicolumn{3}{l|}{$\begin{array}{l}\text { Onset of } \\
\text { myoclonic jerks }\end{array}$} & $\begin{array}{l}\text { Recovery } \\
\text { time }\end{array}$ \\
& Mean & SE & Mean & SE & Mean & SE & Mean & SE & Mean & SE \\
\hline Control & 2.58 & 0.16 & 1.67 & 0.33 & 1.24 & 0.19 & 2.59 & 0.16 & 34.88 & 5.60 \\
\hline Sodium Valproate $180 \mathrm{mg} / \mathrm{kg}$ & $0.00^{*}$ & 0.00 & $0.00^{*}$ & 0.00 & $0.00^{*}$ & 0.00 & 4.87 & 3.10 & $1.36^{*}$ & 0.89 \\
\hline Atorvastatin $3.6 \mathrm{mg} / \mathrm{kg}$ & 4.00 & 4.00 & 0.17 & 0.17 & 3.33 & 3.33 & 3.32 & 1.50 & 4.45 & 2.43 \\
\hline Atorvastatin $7.5 \mathrm{mg} / \mathrm{kg}$ & $0.00^{*}$ & 0.00 & $0.00^{*}$ & 0.00 & $00.0^{*}$ & 0.00 & 5.71 & 3.65 & $1.93^{*}$ & 1.23 \\
\hline$* \mathrm{p}<0.05$ & & & & & & & & & & \\
\hline
\end{tabular}

In the present study, phenytoin $36 \mathrm{mg} / \mathrm{kg}$ protected rats from HLE in the MES model. Whereas, atorvastatin in different doses (3.6 and $7.5 \mathrm{mg} / \mathrm{kg}$ ) could not afford protection from electroshock induced seizures.

Many studies have been conducted in the past to evaluate effect of atorvastatin in animal models of seizures. Atorvastatin has shown varied effects in different studies in the MES model of seizures. In the studies under taken by Rajangam $\mathbf{J}$ et al and Kumar $\mathrm{S}$ et al administration of atorvastatin in animals did not offer protection against HLE produced by MES. ${ }^{6,7}$ These results are in accordance to this study, concluding that acute administration of atorvastatin in MES model fails to protect animals from seizure.

In the present study, atorvastatin significantly reduced seizure number, duration and prolonged seizure onset time in the PTZ model. The postictal recovery was faster and better compared to the control group. All these findings are indicative of its protective effects in this model.

In a study performed by Nayak $\mathrm{V}$ et al, the effect of chronic administration of atorvastatin $(7.2 \mathrm{mg} / \mathrm{kg}$ oral was given for 30 days) in rats was evaluated in PTZ (60 $\mathrm{mg} / \mathrm{kg}$ i.p) induced seizure model. ${ }^{8}$ Atorvastatin here significantly reduced duration of seizures in comparison with control group. It also increased tissue glutathione levels and significantly reduced malanodialdehyde (MDA) levels. MDA is used as a marker to measure the level of oxidative damage in tissues. Neuronal hyperexcitability and oxidative stress has been suggested to be responsible for various neurological disorders including epilepsy. In similarity to this study, in the present study, Atorvastatin has protected rats from seizures and could have done so by a similar mechanism in preventing PTZ induced seizures.

Moazzami $\mathrm{K}$ et al conducted a study using atorvastatin, L-NAME (NOS inhibitor) and L-arginine (NO precursor) to assess the role of $\mathrm{NO}$ in seizures in which they concluded that atorvastatin's anticonvulsant action was abolished by its combination with L-NAME and potentiated on combining with $\mathrm{L}$-arginine indicating that
NO pathway has definitive role to play in antiepileptic action of atorvastatin. ${ }^{11}$

Results of the present study have demonstrated a similar reduction in severity of seizures with atorvastatin in PTZ seizure which could be probably mediated through the protective NO pathway. As statins have exhibited to modulate NO by up-regulating endothelial NOS expression and increase in NO production, it can be postulated that this could be the probable mechanism by which statins modulate epileptic seizures.

Neuronal hyperexcitability is also another proven cause of seizures. Few studies in this direction have concluded that attenuation of the glutamate induced increase of intracellular calcium which is associated with increased NMDA receptor functions can decrease seizure activity. ${ }^{12}$

\section{CONCLUSION}

Therefore, findings of present study indicate that atorvastatin in different doses decreases the seizure activity induced by PTZ chemical convulsant. It could thus be a potential drug for treatment of absence seizures. It also was seen to help in faster and better recovery during postictal period as it reduced time for recovery after onset of seizures. The mechanism of these effects could be attributed to its antioxidant property by increasing $\mathrm{NO}$ and replenishing glutathione stores and/or attenuation of the glutaminergic neuronal hyper excitation. However, this study does not delineate these mechanisms nevertheless it has paved way to further systematic studies to confirm the anticonvulsant role of atorvastatin and its probable mechanisms. The present study clinically would imply that atorvastatin can be used in patients requiring it for dyslipidaemia and also diagnosed with co-existing absence seizures. This would reduce the need of two drugs to be used separately to treat the two disorders, if atorvastatin is proved useful for absence seizures in future clinical trials.

\section{ACKNOWLEDGEMENTS}

The authors are grateful to the Principal and the Head of the Department of Pharmacology SDM College of Medical Sciences and Hospital Dharwad, for providing 
facilities. Thanks to Mr. Anand Kulkarni and Mr. Guddappa for their skilful assistance and Mr. Javali, Biostastician for analysis of the data. Authors acknowledge the branch Manager and all others of Mankind Pharmaceuticals, Hubballi, Karnataka for free drug samples.

Funding: No funding sources

Conflict of interest: None declared

Ethical approval: The study was approved by the Institutional Ethics Committee

\section{REFERENCES}

1. Epilepsy. World Health Organisation, 2016. Available at: http://www.who.int/mediacentre/factsheets/fs999/en/. Accessed on 14 April 2016.

2. Devi PU, Manocha A, Vohora D. Seizures, antiepileptics, antioxidants and oxidative stress: an insight for researchers. Expert Opin Pharmacother. 2008;9(18):3169-77.

3. Shafaroodi H, Mezi L, Fakhrzad A, Hassanipour M, Rezayat M, Dehpour AR. The involvement of nitric oxide in the anti- seizure effect of acute Atorvastatin treatment in mice. Neurol Res. 2012;34(9):847-53.

4. Ramirez C, Tercero I, Pineda A, Burgos JS. Simvastatin is the statin that most efficiently protects against kinate-induced excitotoxicity and memory impairment. J. Alzheimers Dis. 2011;24(1):161-74.

5. Moezi L, Shafaroodi H, Hassanpuri M, Fakhrzad A, Hassanpour S, Dehpour AR. Chronic administration of atorvastatin induced anti-convulsant effects in mice: the role of nitric oxide. Epilepsy Behav. 2012;23(4):399-404.

6. Rajangam J, Manogna K, Mounica K, Padma C, Sawthi A. Behavioral influence of atorvastatin alone and in combination with antiepileptics against electroconvulsions in mice. Malays. J. Med. Biol. Res. 2015;2(3):224-30.

7. Kumar S, Megha M, Chogtu B, Bairy LK. Effects of acute and chronic administration of losartan, atorvastatin and their combination on animal models of epilepsy. Research journal of pharmaceutical, biological and chemical sciences. 2015;6(4):1795801.

8. Nayak V, Adiga S, Poornima BM, Sharma R, Garg A, Shetty M. Effect of chronic administration of atorvastatin, simvastatin and lovastatin on animal model of epilepsy. International journal of current research and review. 2013;5(19):61-5.

9. Gupta YK, Malhotra J, George B, Kulkarni SK. Methods and considerations for experimental evaluation of antiepileptic drugs. Indian J Physiol Pharmacol. 1999;43(1):25-43.

10. Louis JW, Papanicolaou J, Summers JR, Vajda JF. Role of beta-adrenoreceptors in the control of pentanyltetrazol- induced convulsion in rats. $\mathrm{Br} \mathrm{J}$ Pharmacol. 1982;75(3):441-6.

11. Moazzami K, Emamzadeh-Fard H, Shabani M. Anticonvulsant effect of atorvastatin on pentylenetetrazole-induced seizure in mice: the role of nitric oxide pathway. Fundam clin pharmacol. 2013;27(4):44-7.

12. Bosel J, Gandor F, Harms C, Synowitz M, Harms U, Djoufack PC, et al. Neuroprotective effects of atorvastatin against glutamate-induced excitotoxicity in primary cortical neurones. $\mathrm{J}$ Neurochem. 2005;92(6):1386-98.

Cite this article as: Singh AP, Radhika MS.

Potential anti-seizure activity of atorvastatin in rat models of seizure. Int J Basic Clin Pharmacol 2017;6:35-8. 